\title{
TEORI EKOLOGI BRONFENBRENNER SEBAGAI SEBUAH PENDEKATAN DALAM PENGEMBANGAN KURIKULUM PENDIDIKAN AGAMA ISLAM
}

\author{
Unik Hanifah Salsabila \\ Sekolah Tinggi Ilmu Tarbiyah Madani Yogyakarta \\ E-mail: unikhanifah14@gmail.com
}

\begin{abstract}
Abstrak
Salah satu tantangan terbesar bagi pengembangan kurikulum Pendidikan Agama Islam ialah pada ranah internalisasi nilai dalam menumbuhkan karakter dan habit peserta didik, sehingga materi Pendidikan Agama Islam tidak sekedar berorientasi pada aspek kognitif semata. Adapun realitas adanya interelasi yang dinamis antara peserta didik dengan lingkungannya dalam berkontribusi terhadap tumbuhnya karakter dan habit tertentu dalam diri peserta didik, rupanya menjadi permasalahan sekaligus solusi bagi upaya internalisasi nilai tersebut. Dalam konteks ini, teori ekologi perkembangan Brofenbrenner membantu mengkaji efektifitas pengembangan kurikulum Pendidikan Agama Islam secara tersistem dan terpola di lingkup satuan pendidikan dengan memanfaatkan subsistem sekolah sebagai lingkungan mikrosistem terdekat dalam keseharian peserta didik.
\end{abstract}

Kata Kunci: Kurikulum, Pendidikan Agama Islam, Brofenbrenner, Ekologi.

\section{Abstract}

One of the biggest challenges for Islamic religious education curriculum development is in the realm of internalizing the value in fostering character and habit learners, educational material so that Islam is not just a cognitive aspectoriented sheer. As for the reality of the existence of a dynamic interelasi between learners with their surroundings in contributing to the growth of a particular character and habit in students, apparently being a problem at the same time solutions for the efforts of internalization that value. In this context, the development of ecological theory Brofenbrenner help assess the effectiveness of Islamic religious education curriculum development systematically and patterned on the unit sphere of education by 
Unik Hanifah Salsabila : Teori Ekologi Bronfenbrenner sebagai Sebuah Pendekatan dalam Pengembangan Kurikulum Pendidikan Agama Islam

making use of the school as an environment subsystem the closest mikrosistem in the daily life of learners.

Keywords: Curriculum, Islamic Education, Brofenbrenner, Ecology.

\section{A. PENDAhUluan}

Pendidikan Agama Islam merupakan komponen materi pelajaran yang berorientasi pada proses mendidikkan agama Islam, yakni berupa penyampaian materi-materi keagamaan yang sudah ada, untuk kemudian dipelajari dan diamalkan. Hal ini tentunya menjadikan Pendidikan Agama Islam cenderung berada pada ranah amali bukan filosofis. Pendidikan sebagai usaha membina dan mengembangkan pribadi manusia yang meliputi aspek rohaniah dan jasmaniah harus berlangsung secara bertahap. Sebab tidak ada satupun makhluk ciptaan Allah yang secara langsung tercipta dengan sempurna tanpa melalui suatu proses. 169

Muhaimin menyatakan bahwa Pendidikan Agama Islam berupaya mendidikkan agama Islam atau ajaran Islam dan nilai-nilainya agar menjadi pandangan dan sikap hidup seseorang. Aktivitas mendidikkan agama Islam bertujuan untuk membantu seseorang atau sekelompok peserta didik dalam menanamkan dan menumbuhkembangkan ajaran Islam dan nilai-nilainya untuk dijadikan sebagai pandangan hidup. 170 Dalam konteks ini, tentunya menjadi hal yang mendasar ketika pengembangan Pendidikan Agama Islam

169 H. Muzayyin Arifin, Filsafat Pendidikan Islam, (Jakarta: Bumi Aksara, 2003), cet-1,

hlm. 12.

170 Ahmad Tafsir, Ilmu Pendidikan Dalam Perspektif Islam, (Bandung: PT. Remaja Rosdakarya, 1994), cet-2, hlm. 7-8. 
Unik Hanifah Salsabila : Teori Ekologi Bronfenbrenner sebagai Sebuah Pendekatan dalam Pengembangan Kurikulum Pendidikan Agama Islam

tidak hanya berakhir pada tujuan kognitif semata, melainkan justru penekanannya terdapat pada penanaman karakter dan habit dalam diri setiap peserta didik, di mana lingkungan sekolah menjadi mediator utama dalam pengkondisian tersebut.

Sistem pendidikan yang ada saat ini cenderung terkesan mekanistik sehingga mematikan kreativitas individu. Megawangi menyatakan bahwa, menurunnya moralitas anak salah satu penyebabnya adalah pendidikan yang cenderung mengutamakan aspek kognitif saja dan melihat hasil belajar berdasarkan ranking yang diperoleh anak. ${ }^{171} \mathrm{Hal}$ tersebut berdampak pada terabaikannya proses pembentukan karakter dan habit, yang sesungguhnya jauh lebih penting dari prestasi akademis. Akibatnya individu tumbuh menjadi orang yang pintar tapi tidak berkarakter positif, kondisi ini justru sangat berbahaya ketika mereka kembali ke masyarakat.

Hal senada juga dikemukakan oleh Zubaedi bahwa pembentukan karakter harus berkaitan dengan aspek kognitif yang diperkuat dengan aspek afektif karena jika sistem pendidikan masih lebih menekankan pada kognisi semata maka akan semakin memicu lunturnya karakter yang telah dibangun berabad-abad yaitu keramahan, kesopanan, toleransi, solidaritas sosial, termasuk kemampuan dalam menghadapi masalah. ${ }^{172}$ Adapun faktor pembentuk karakter dan habit dalam diri tiap peserta didik memang teramat kompleks, sehingga diperlukan adanya berbagai pendekatan yang komprehensif terkait pengembangan kurikulum

171 Megawangi, Character Building (Tinjuan Berbagai Aspek), (Yogyakarta: Tiara Wacana, 2008), hlm. 67.

172 Zubaedi, Pendidikan Berbasis Masyarakat: Upaya Menawarkan Berbagai Problem Sosial, (Yogyakarta: Pustaka Pelajar, 2007), hlm. 54. 
Unik Hanifah Salsabila : Teori Ekologi Bronfenbrenner sebagai Sebuah Pendekatan dalam Pengembangan Kurikulum Pendidikan Agama Islam

Pendidikan Agama Islam yang efektif untuk dapat diimplementasikan di lingkup satuan pendidikan, salah satunya pendekatan melalui teori pembentukan karakter ekologis.

Teori ekologi merupakan sebuah teori yang menekankan pada pengaruh lingkungan dalam perkembangan setiap individu di mana perkembangan peserta didik merupakan hasil interaksi antara alam sekitar dengan peserta didik tersebut. Dalam konteks ini, interaksi antara peserta didik dengan lingkungan sekitar dinilai secara signifikan dapat mempengaruhi proses pertumbuhan dan perkembangannya. Teori ekologi perkembangan merupakan salah satu teori yang mencoba menguraikan pengembangkan pendidikan karakter anak dengan pendekatan ekologi. Pendekatan tersebut dilakukan melalui lima subsistem yang relevan dengan pengembangan kurikulum Pendidikan Agama Islam di lingkungan sekolah yakni, 1) mikrosistem, yang mengkaji setting di mana individu hidup, 2) mesosistem, mengkaji interaksi antar faktor-faktor dalam sistem mikro yang meliputi hubungan antara beberapa mikrosistem atau beberapa konteks, 3) eksosistem, mengkaji pengalaman- pengalaman dalam setting sosial lain di mana anak tidak memiliki peran yang aktif tetapi berefek pada pengembangan karakternya, 4) makrosistem, kajian tentang peran kebudayaan dalam pendidikan karakter, dan 5) kronosistem, yang meliputi kajian terkait pemolaan peristiwa-peristiwa sepanjang rangkaian kehidupan dan keadaan sosiohistoris.

Penanaman habit dan karakter dalam Pendidikan Agama Islam belum cukup jika hanya dikaji dari aspek contentnya saja. Diperlukan pendekatan yang lebih holistik 
Unik Hanifah Salsabila : Teori Ekologi Bronfenbrenner sebagai Sebuah Pendekatan dalam Pengembangan Kurikulum Pendidikan Agama Islam

untuk menemukan konsep kurikulum Pendidikan Agama Islam yang sistemik, yaitu dengan mengkaji interaksi "the person-inenvironment". ${ }^{173}$ Dalam konteks ini, teori ekologi perkembangan akan membantu memberikan landasan bagaimana mengkaji perkembangan anak pada lingkungan tempat dia bertumbuh dan menjalani masa kanak-kanak, dengan melakukan pengkondisian setting yang direncanakan sesuai dengan kebutuhan perkembangannya sehingga akan terbentuk karakter dan habit yang diharapkan.

\section{B. PEMBahasan}

\section{Teori Ekologi Perkembangan Brofenbenner}

Teori ekologi perkembangan anak diperkenalkan oleh Uri Bronfenbrenner, seseorang ahli psikologi dari Cornell University Amerika Serikat. ${ }^{174}$ Teori ekologi memandang bahwa perkembangan manusia dipengaruhi oleh konteks lingkungan. Hubungan timbal balik antara individu dengan lingkungan akan membentuk tingkah laku individu tersebut. Informasi lingkungan tempat tinggal anak akan menggambarkan, mengorganisasi, dan mengklarifikasi efek dari lingkungan yang bervariasi. Berofenbrenner menyebutkan adanya lima sistem lingkungan berlapis yang saling berkaitan, yaitu mikrosistem, mesosistem, ekosistem, makrosistem, dan kronosistem.

Secara sederhana interaksi tersebut tampak pada gambar berikut ini:

173 Tri Na'imah, Pendidikan Karakter (Kajian Dari Teori Ekologi Perkembangan), (Prosiding Seminar Nasional Psikologi Islami, 21 April 2012), hlm. 160 .

174 Bronfenbrenner, "Ecology of the Family As A Context for Human Development Research Perspectives", Developmental Psychology, 22 Juni 1986. 
Unik Hanifah Salsabila : Teori Ekologi Bronfenbrenner sebagai Sebuah Pendekatan dalam Pengembangan Kurikulum Pendidikan Agama Islam

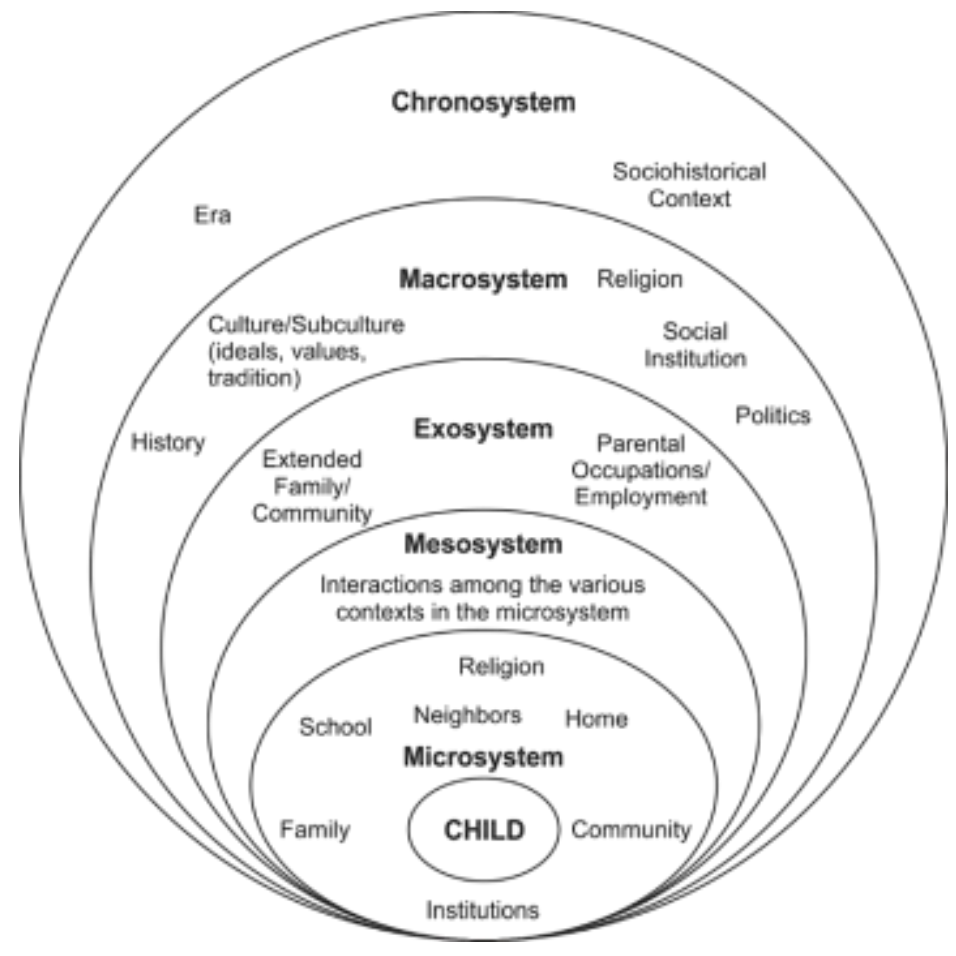

Gambar 1.

Teori Ekologi Urie Bronfenbrenner (Biddle, et.al, 2014: 102)

Satu hal yang terpenting dalam teori ekologi perkembangan Brofenbenner adalah bahwa pengkajian perkembangan anak dari subsistem manapun, harus berpusat pada anak, artinya pengalaman hidup anak yang dianggap menjadi penggerak utama bagi perkembangan karakter dan habitnya di kemudian hari. Masing-masing subsistem dalam teori Brefenbrenner tersebut dapat diuraikan sebagaimana berikut:

a. Mikrosistem

Mikrosistem merupakan lingkungan yang paling dekat dengan pribadi peserta didik yaitu meliputi keluarga, 
Unik Hanifah Salsabila : Teori Ekologi Bronfenbrenner sebagai Sebuah Pendekatan dalam Pengembangan Kurikulum Pendidikan Agama Islam

guru, individu, teman-teman sebaya, sekolah, lingkungan tempat tinggal, dan hal-hal lain yang sehari-hari ditemui oleh peserta didik. Dalam mikrosistem inilah terjadi interaksi yang paling langsung dengan agen-agen sosial tersebut. Individu tidak dipandang sebagai penerima pengalaman yang pasif dalam setting ini, tetapi individu bahkan ikut aktif membangun setting pada mikrosistem ini. Karakteristik individu dan karakteristik lingkungan akan berkontribusi dalam proses interaktif yang terjadi, sehingga membentuk sebuah karakter dan habit tertentu. Keluarga terutama orangtua dan lingkungan sekolah merupakan agen sosialisasi terdekat dalam kehidupan setiap individu, sehingga keluarga mempunyai pengaruh besar pada pembentukan karakter dan habit seseorang.

b. Mesosistem

Mesosistem mencakup interaksi di antara mikrosistem di mana masalah yang terjadi dalam sebuah mikrosistem akan berpengaruh pada kondisi mikrosistem yang lain. 175 Misalnya hubungan antara pengalaman keluarga dengan pengalaman sekolah, pengalaman sekolah dengan pengalaman keagamaan, dan pengalaman keluarga dengan pengalaman teman sebaya, serta hubungan keluarga dengan tetangga.

Dalam kaitannya dengan proses pendidikan, tentunya pengalaman

apapun yang didapatkan oleh peserta didik di rumah akan ikut mempengaruhi kondisi peserta didik di sekolah baik

175 Bronfenbrenner, U., Morris, P. A., The Ecology of Developmental Processes. In W. Damon (Series Ed.) \& R. M. Lerner (Vol. Ed.), Handbook of Child Psychology: Vol. 1: Theoretical Models of Human Development. (New York: Wiley, 1998). 
Unik Hanifah Salsabila : Teori Ekologi Bronfenbrenner sebagai Sebuah Pendekatan dalam Pengembangan Kurikulum Pendidikan Agama Islam

secara langsung maupun tidak. Sebagai contoh, ada tidaknya dukungan atau perhatian keluarga terhadap kebutuhan literasi tentunya akan mempengaruhi kinerja peserta didik di sekolah. Sebaliknya, dukungan sekolah dan keluarga akan mempengaruhi seberapa jauh peserta didik akan menghargai pentingnya literasi.

c. Ekosistem

Eksosistem adalah sistem sosial yang lebih besar di mana anak tidak terlibat interaksi secara langsung, akan tetapi dapat berpengaruh terhadap perkembangan karakter anak. Sebagai contoh, jam kerja orangtua bertambah yang menyebabkan peserta didik kehilangan interaksi dengan orangtuanya sehingga kurangnya keterlibatan orangtua dalam pola asuh tersebut tentunya mempengaruhi perkembangan anak. Subsistem dari eksosistem lain yang secara tidak langsung menyentuh pribadi peserta didik akan tetapi berpengaruh besar adalah koran, televisi, dokter, keluarga besar, dan lain sebagainya.

d. Makrosistem

Makrosistem adalah sistem lapisan terluar dari lingkungan anak. Subsistem makrosistem terdiri dari ideologi negara, pemerintah, tradisi, agama, hukum, adat istiadat, budaya, nilai masyarakat secara umum, dan lain sebagainya, di mana individu berada. Prinsip-prinsip yang terdapat dalam lapisan makrosistem tersebut akan berpengaruh pada keseluruhan interaksi di semua lapisan. Misalnya, jika kebudayaan masyarakat menggariskan bahwa orangtua bertanggungjawab untuk membesarkan anak-anaknya, maka hal tersebut akan mempengaruhi struktur di mana orangtua akan menjalankan fungsi 
Unik Hanifah Salsabila : Teori Ekologi Bronfenbrenner sebagai Sebuah Pendekatan dalam Pengembangan Kurikulum Pendidikan Agama Islam

psikoedukasinya. Menurut Berk, budaya yang dimaksud dalam subsistem ini adalah pola tingkah laku, kepercayaan, dan semua produk dari sekelompok manusia yang diwariskan dari generasi ke generasi. ${ }^{176}$

e. Kronosistem

Kronosistem mencakup pengaruh lingkungan dari waktu ke waktu beserta caranya mempengaruhi perkembangan dan perilaku. 177 Contohnya seperti perkembangan teknologi dengan produk-produk turunannya, seperti internet dan gadget, membuat peserta didik mahir, nyaman, dan terbiasa menggunakannya untuk pendidikan maupun hiburan. Demikian halnya dengan maraknya fenomena wanita karir akibat industrialisasi, telah mengubah kehidupan keluarga. Perhatian ibu terhadap anak menjadi berkurang. Kronosistem meliputi keterpolaan peristiwaperistiwa sepanjang rangkaian kehidupan dan keadaan sosiohistoris.

Berdasarkan uraian tersebut, tampak betapa kompleksnya factor-faktor yang dapat mempengaruhi karakter dan habit setiap peserta didik. Meskipun demikian, perkembangan karakter dan habit peserta didik pada usia dini akan cenderung terpusat pada lingkungan mikrosistem. Perilaku peserta didik akan berkembang ke arah negatif atau positif sangat bergantung pada dukungan lingkungan mikrosistem yang diberikan. Dalam konteks lembaga pendidikan peserta didik usia dini, terdapat elemen-elemen

176 Berk, Child Development (5th ed.), (Boston: Allyn and Bacon, 2000), hlm. 321.

177 Sigit Purnama, "Elementsof Child-Friendly Environment: The Effort to Provide an Ant-I Violence Learning Environment", Indonesian Journal of Islamic Early Childhood Education, Vol. 1 No. 1, December 2016, hlm. 131140. 
Unik Hanifah Salsabila : Teori Ekologi Bronfenbrenner sebagai Sebuah Pendekatan dalam Pengembangan Kurikulum Pendidikan Agama Islam

kurikulum sekolah yang mampu menyediakan lingkungan yang mendukung terhadap perkembangan peserta didik ke arah positif. Dengan demikian, salah satu upaya yang dapat dilakukan dalam mengimplementasikan Pendidikan Agama Islam secara tersistem dan terpola sehingga terinternalisasi menjadi sebuah karakter dan habit adalah dengan menyediakan lingkungan yang aman, nyaman, dan mampu menstimuli aspek-aspek perkembangan peserta didik usia dini di lingkup satuan pendidikan.

Menurut Bronfenbrenner, dalam mengkaji suatu masalah berdasar teori ekologi maka harus melibatkan aspekaspek prediktor yang mewakili empat komponen, yaitu konteks masalahnya, orang yang terlibat, proses, dan waktu. ${ }^{178}$ Oleh karena itu pengkajian teori ekologi terhadap pengembangan kurikulum Pendidikan Agama Islam akan meliputi salah satu aspek prediktornya yang paling relevan, yakni karakteristik lingkungan di mana pendidikan karakter dan penanaman habit itu berlangsung (konteks), karakteristik individu (peserta didik), dan proses pendidikan karakter serta penanaman habit di lingkup satuan pendidikan.

\section{Pengembangan Kurikulum Pendidikan Agama Islam dalam}

\section{Kajian Teori Ekologi Brofenbrenner}

Kurikulum Pendidikan Agama Islam berorientasi pada proses transfer pengetahuan, cara berpikir (mindset), sikap (behaviour), dan perilaku (attitude) melalui seperangkat pengetahuan dan nilai-nilai yang terdapat dalam al Qur'an dan al Hadist. Dengan berkembangnya ilmu pengetahuan, Pendidikan Agama Islam juga dituntut untuk dapat mengembangkan diri baik dari aspek teoritis maupun aplikatif

178 Tri, Na'imah ..., hlm. 159-166. 
Unik Hanifah Salsabila : Teori Ekologi Bronfenbrenner sebagai Sebuah Pendekatan dalam Pengembangan Kurikulum Pendidikan Agama Islam

sehingga peranannya dalam membangun kerangka psikologisideologis peserta didik dapat terimplementasikan dengan upaya dan proses penanaman sesuatu (pendidikan) secara continue, serta adanya hubungan timbal balik antara pendidik, peserta didik, dan akhlakul karimah sebagai tujuan akhir dengan tetap memperhatikan aspek epistemologi terkait pembinaan dan pengoptimalan potensi; penanaman nilai-nilai Islam dalam jiwa, rasa, dan pikir; serta keserasian dan keseimbangan.

Pendidikan Agama Islam sebagai bagian integral dari keseluruhan tatanan sistem pendidikan nasional, harus dikembangkan dan dilaksanakan secara sistemik dan holistik melalui tiga pilar utama pelaksanaan proses pendidikan, yakni satuan pendidikan, keluarga, dan masyarakat. Hal ini juga konsisten dengan konsep tanggungjawab pendidikan nasional yang berada pada sekolah, keluarga, dan masyarakat. Setiap pilar merupakan suatu entitas pendidikan yang mengembangkan nilai-nilai (nilai ideal, nilai instrumental, dan nilai praksis) melalui proses intervensi (campur tangan antar elemen pendidikan) dan habituasi (kehidupan dunia pendidikan). 179

Dalam konteks ini, sekolah sebagai penyelenggara pendidikan yang sistematis merupakan salah satu faktor utama bagi keberlangsungan penanaman karakter dan habit peserta didik yang sesuai dengan nilai-nilai Pendidikan Agama Islam melalui konsep perencanaan setting lingkungan mikrosistem yang disesuaikan dengan tingkat perkembangan

179 Budimansyah, dkk. Model Pendidikan Karakter di Perguruan Tinggi Penguatan PKn, Layanan Bimbingan Konseling dan KKN Tematik di Universitas Pendidikan Indonesia. (Bandung: Universitas Pendidikan Indonesia, 2010), hlm. 5. 
Unik Hanifah Salsabila : Teori Ekologi Bronfenbrenner sebagai Sebuah Pendekatan dalam Pengembangan Kurikulum Pendidikan Agama Islam

peserta didik. Jika tujuan dan proses pengembangan kurikulum Pendidikan Agama Islam di lingkup satuan pendidikan tersebut disandingkan dengan teori ekologi perkembangan Brofenbrenner, maka kajian utama pada penulisan ini akan mengacu secara khusus pada subsistem budaya sekolah yang notabenenya merupakan budaya lingkungan mikrosistem dengan intensitas interaksi tertinggi dalam keseharian peserta didik.

\section{Subsistem Budaya Sekolah}

Lingkungan sekolah sebagai lingkungan pendidikan kedua setelah keluarga menempati peran penting dalam pendidikan karakter dan habit peserta didik. ${ }^{180}$ Menurut Colgan sekolah adalah tempat yang sangat strategis untuk pendidikan karakter dan penanaman habit tertentu, karena semua peserta didik dari berbagai lapisan masyarakat akan mengenyam pendidikan di sekolah. Selain itu, sebagian besar waktu peserta didik saat ini banyak dihabiskan di sekolah, sehingga sekolah berperan aktif terhadap pembentukan karakter siswa. ${ }^{181}$ Menilik pada realitas tersebut maka dapat diasumsikan bahwa internalisasi karakter dapat ditumbuhkan melalui atmosfir sekolah yaitu budaya sekolah.

Budaya sekolah merupakan nilai-nilai dominan yang didukung oleh sekolah atau falsafah yang menuntun kebijakan sekolah terhadap semua unsur dan komponen sekolah termasuk stakeholders pendidikan. Pada awalnya budaya sekolah dibentuk dalam jaringan yang sifatnya formal, akan

180 Teodorescu dan Andrei, "Faculty and Peers Influences on Academic Integrity: College Cheating In Romania”, Journal of Higher education, Vol. 3 tahun 2008, hlm. 1-12.

181 Colgan dalam Azhar Aziz, "Pengembangan Karakter Anak Melalui Pendidikan Karakter", Jurnal Intelektua, Vol. 3, hlm. 1-6. 
Unik Hanifah Salsabila : Teori Ekologi Bronfenbrenner sebagai Sebuah Pendekatan dalam Pengembangan Kurikulum Pendidikan Agama Islam

tetapi dalam perkembangannya secara perlahan budaya sekolah akan diinternalisasi dan menjadi ciri khas sekolah tersebut bahkan dalam jangka panjang akan terinternalisasi dalam diri setiap peserta didik. Dalam kajian ekologi, perkembangan budaya sekolah merupakan subsistem yang memberi kesempatan peserta didik untuk belajar memahami nilai dan aturan serta mewujudkannya dalam bentuk karakter dan habit yang baik.

Kurikulum Pendidikan Agama Islam tidak dapat diimplementasikan secara parsial dalam upaya membangun budaya, sehingga sekolah harus dapat membawa peserta didik kepada pengenalan nilai secara kognitif, penghayatan nilai secara afektif, dan pengalaman nilai secara nyata. Menurut Kurniawan, hal tersebut bisa tercapai jika nilai Pendidikan Agama Islam di lingkungan sekolah diintegrasikan dalam pembelajaran pada setiap mata pembelajaran. Materi pembelajaran yang berkaitan dengan norma atau nilai-nilai pada setiap mata pelajaran perlu dikembangkan, dieksplisitkan, dikaitkan dengan konteks kehidupan seharihari. ${ }^{182}$ Dengan cara seperti itu maka internalisasi norma atau nilai-nilai akan semakin mudah terjadi pada anak. Di antara pola integrasi nilai Pendidikan Agama Islam dalam rangka membangun kultur lingkungan pada subsistem sekolah adalah sebagai berikut:

a. Menciptakan Lingkungan Ramah Anak

Hasil penelitian Engineer menunjukkan bahwa anak yang dibesarkan, diasuh, dan dididik di lingkungan yang

182 Kurniawan, Pendidikan Karakter: Konsepsi dan Implementasinya Secara Terpadu di Lingkungan Keluarga, Sekolah, Perguruan Tinggi, dan Masyarakat, (Yogyakarta: Ar-Ruzz Media, 2013), hlm. 47. 
Unik Hanifah Salsabila : Teori Ekologi Bronfenbrenner sebagai Sebuah Pendekatan dalam Pengembangan Kurikulum Pendidikan Agama Islam

ramah, akan cenderung lebih sehat, bahagia, dan berprestasi, dibandingkan dengan anak yang tidak dibesarkan di lingkungan yang ramah. ${ }^{183}$ Lingkungan yang ramah adalah lingkungan yang mengundang, nyaman, sehat, aman, mendukung, menantang, dan penuh penghargaan. 184 Oleh karena itu, lingkungan sekolah seharusnya didesain sedemikian rupa sehingga memenuhi kriteria lingkungan yang ramah bagi perkembangan peserta didik. Dalam hal ini pendidik berperan aktif untuk menumbuhkan keteladanan terhadap perilaku positif yang hendak diinternalisasikan dalam diri peserta didik.

b. Program Pengembangan Diri (Life Skills)

Life skills adalah salah satu upaya pendidikan dalam rangka memberikan kecakapan personal, kecakapan sosial, kecakapan intelektual, dan kecakapan vokasional untuk bekerja, berusaha, dan hidup mandiri. Orientasi pengembangan life skills berupa membangun sikap kemandirian untuk mendapatkan keterampilan sebagai bekal dalam beraktifitas dan mengembangkan diri (skilled orientation). Sebagaimana dikatakan Broling, life skills atau kecakapan hidup adalah interaksi berbagai pengetahuan dan kecakapan yang sangat penting untuk dimiliki seseorang sehingga mereka dapat hidup mandiri. ${ }^{185}$

Memiliki kecakapan hidup akan membuat peserta didik berhasil beradaptasi di lingkungan manapun berada

183 Moh. Haitami Salim dan Samsul Kurniawan, Studi Ilmu Pendidikan Islam, (Yogyakarta: Ar-ruzz Media, 2012), hlm. 268.

184 George Morisson, Fundamentals of Early Childhood Education, Terj. Suci Romadhona dan Apri Widiastuti, (Jakarta: Indeks, 2012), hlm. 204. 185 A. Suhaenah Suparno, Membangun Kompetensi Belajar, (Jakarta: Direktorat Jenderal Pendidikan Tinggi Departemen Pendidikan Nasional, 2003) hlm. 43. 
Unik Hanifah Salsabila : Teori Ekologi Bronfenbrenner sebagai Sebuah Pendekatan dalam Pengembangan Kurikulum Pendidikan Agama Islam

dan mampu mempertahankan bahkan membangun karakter dan habit positif bagi lingkungan mikrosistemnya. Life skills yang baik dan berkarakter akan membuat peserta didik menyadari betul potensi terbaik dalam dirinya sehingga diasumsikan akan melahirkan pandangan hidup yang utuh sesuai dengan budaya yang diinternalisasikan oleh sekolah, khususnya dalam kaitannya dengan kurikulum Pendidikan Agama Islam.

c. Gerakan Lingkungan Positif

Dalam membangun budaya sekolah yang positif sesuai dengan nilai-nilai Pendidikan Agama Islam maka diperlukan adanya gerakan massif yang nyata pada keseluruhan elemen sekolah, di mana peserta didik ikut berperan aktif sebagai penggagas dan pelaksana dari gerakan tersebut. Sebagai contoh, sosialisasi gerakan 5S (senyum, salam, salim, sapa, dan santun) dengan menjadikan peserta didik sebagai supervisor bagi pelaksana gerakan tersebut sehingga masing-masing peserta didik menjadi termotivasi untuk melaksanakan tanggungjawabnya.

d. Outing dan Field Trip

Salah satu langkah integratif dalam menginternalisasikan nilai Pendidikan Agama Islam melalui berbagai mata pelajaran di sekolah adalah dengan menjadikannya terpadu dengan kegiatan-kegiatan yang cenderung bersifat real life experience. Proses edukasi yang menimbulkan pengalaman positif di lingkungan mikrosistemnya tentu akan meninggalkan ingatan positif dalam diri peserta didik yang secara disengaja maupun tidak akan mempermudah tumbuhnya proses internalisasi 
Unik Hanifah Salsabila : Teori Ekologi Bronfenbrenner sebagai Sebuah Pendekatan dalam Pengembangan Kurikulum Pendidikan Agama Islam

karakter dan habit yang diharapkan. Penyampaian nilai melalui proses yang menyenangkan dapat menstimuli peserta didik secara efektif pada usia perkembangannya melalui lingkungan mikrosistem yang paling berpengaruh.

\section{PENUTUP}

Berdasarkan pemaparan tersebut di atas, dapat disimpulkan bahwa teori ekologi perkembangan mengkaji adanya interelasi yang dinamis dan kompleks antara peserta didik dengan lingkungannya sehingga secara sadar maupun tidak akan berkontribusi positif terhadap tumbuhnya karakter dan habit tertentu dalam diri peserta didik di kemudian hari. Dalam konteks ini, sekolah sebagai salah satu bagian terdekat dalam lingkungan mikrosistem yang menjadi tempat berkembangnya peserta didik, memegang peranan penting dalam mentransfer dan menginternalisasikan pengetahuan, cara berpikir (mindset), sikap (behaviour), dan perilaku (attitude) melalui seperangkat pengetahuan dan nilai-nilai dalam Pendidikan Agama Islam.

Oleh karena itu sekolah harus mampu menciptakan lingkungan kegiatan terpadu yang dapat menstimulasi perkembangan anak, seperti lingkungan yang ramah anak, kegiatan edukasi yang menekankan pada pembentukan life skills, pengkondisian gerakan lingkungan positif di sekolah, serta pengkondisian setting real life education dalam mengintegrasikan nilainilai Pendidikan Agama Islam pada setiap mata pelajaran melalui kegiatankegiatan yang menyenangkan. Pemilihan elemen-elemen dalam lingkungan mikrosistem yang tepat sesuai dengan tumbuh kembang peserta didik tersebut diharapkan dapat menjadikan 
Unik Hanifah Salsabila : Teori Ekologi Bronfenbrenner sebagai Sebuah Pendekatan dalam Pengembangan Kurikulum Pendidikan Agama Islam

pengembangan kurikulum Pendidikan Agama Islam mampu secara efektif menyentuh ranah teoritis maupun praksis, sehingga dapat memberikan kontribusi pada terbentuknya karakter dan habit positif peserta didik ketika berinteraksi dengan subsistem lingkungan yang lebih besar. 
Unik Hanifah Salsabila : Teori Ekologi Bronfenbrenner sebagai Sebuah Pendekatan dalam Pengembangan Kurikulum Pendidikan Agama Islam

\section{DAFTAR PUSTAKA}

Arifin, Muzayyin, Filsafat Pendidikan Islam, cet-1, Jakarta: Bumi Aksara, 2003.

Berk, Child Development (5th ed.), Boston: Allyn and Bacon, 2000.

Budimansyah, dkk., Model Pendidikan Karakter di Perguruan Tinggi Penguatan PKn, Layanan Bimbingan Konseling dan KKN Tematik di Universitas Pendidikan Indonesia, Bandung: Universitas Pendidikan Indonesia, 2010.

Bronfenbrenner, "Ecology of the Family As A Context for Human Development Research Perspectives" dalam Developmental Psychology, 22 Juni 1986.

Bronfenbrenner, U., Morris, P. A., The Ecology of Developmental Processes. In W. Damon (Series Ed.) \& R. M. Lerner (Vol. Ed.), dalam Handbook of Child Psychology: Vol. 1: Theoretical Models of Human Development, New York: Wiley, 1998.

Colgan dalam Azhar Aziz, "Pengembangan Karakter Anak Melalui Pendidikan Karakter", Jurnal Intelektua, Vol. 3.

Kurniawan, Pendidikan Karakter: Konsepsi dan Implementasinya Secara Terpadu di Lingkungan Keluarga, Sekolah, Perguruan Tinggi, dan Masyarakat, Yogyakarta: Ar-Ruzz Media, 2013.

Megawangi, Character Building (Tinjuan Berbagai Aspek), Yogyakarta: Tiara Wacana, 2008.

Morisson, George, Fundamentals of Early Childhood Education, Terj. Suci Romadhona dan Apri Widiastuti, Jakarta: Indeks, 2012.

Muhaimin, Rekonstruksi Pendidikan Islam: Dari Paradigma, Manajemen Kelembagaan, Kurikulum hingga Strategi Pembelajaran, Jakarta: Rajawali, 2009.

Na'imah, Tri, "Pendidikan Karakter (Kajian Dari Teori Ekologi Perkembangan)" dalam Prosiding Seminar Nasional Psikologi Islami, 21 April 2012. 
Unik Hanifah Salsabila : Teori Ekologi Bronfenbrenner sebagai Sebuah Pendekatan dalam Pengembangan Kurikulum Pendidikan Agama Islam

Purnama, Sigit "Elementsof Child-Friendly Environment: The Effort to Provide an Ant-I Violence Learning Environment", Indonesian Journal of Islamic Early Childhood Education, Vol. 1 No. 1, December 2016.

Ramsbotham, Oliver Tom Woodhouse and Hugh Miall, Conflict Resolution, USA: Cambridge UK and Polity Press Malden, 2007.

Salim, Moh. Haitami dan Samsul Kurniawan, Studi Ilmu Pendidikan Islam, Yogyakarta: Ar-ruzz Media, 2012.

Suparno, A. Suhaenah, Membangun Kompetensi Belajar, Jakarta: Direktorat Jenderal Pendidikan Tinggi Departemen Pendidikan Nasional, 2003.

Tafsir, Ahmad, Imu Pendidikan Dalam Perspektif Islam, Bandung: PT. Remaja Rosdakarya, cet-2, 1994.

Teodorescu dan Andrei, "Faculty and Peers Influences on Academic Integrity: College Cheating In Romania", Journal of Higher Education, Vol. 3 tahun 2008.

Zubaedi, Pendidikan Berbasis Masyarakat: Upaya Menawarkan Berbagai Problem Sosial, Yogyakarta: Pustaka Pelajar, 2007. 
Unik Hanifah Salsabila : Teori Ekologi Bronfenbrenner sebagai Sebuah Pendekatan dalam Pengembangan Kurikulum Pendidikan Agama Islam

158 Jurnal Komunikasi dan Pendidikan Islam, Volume 7, Nomor 1, Juni 2018 